\title{
FEATURES AND ALGORITHM OF SURGICAL BEHAVIOR IN OSTEOPOROTIC VERTEBRAL FRACTURES
}

\author{
D. Ferdinandov ${ }^{1,2}$, D. Yankov ${ }^{1,2}$ \\ ${ }^{1}$ Clinic of Neurosurgery, Sv. Ivan Rilski University - Sofia \\ ${ }^{2}$ Department of Neurosurgery, Faculty of Neurosurgery, Medical University - Sofia
}

\begin{abstract}
The aim of the current study is to present the possibilities for minimally invasive percutaneous procedures for surgical treatment of osteoporotic compression fractures of the vertebrae (OVCF), expressed in vertebroplasty and balloon kyphoplasty. We compare their therapeutic effect with that of conservative treatment and present conclusions from the world literature regarding the safety of these procedures. Material and methods: We used data from our surgical experience for the last 10 years. We took into account the relevant literature from the global PubMed database and Google Scholar to present randomized clinical trials and meta-analyzes comparing OVCF treatment methods. We analyzed those who assessed the quality of life, pain, and complications of treatment. Results: The world experience shows an excellent result in the short term from the minimally invasive percutaneous procedures. In the long term some authors note a significant overlap of the results with the conservative methods. All studies show a low risk profile in the surgical treatment, as well as comparable results between the two main procedures - vertebroplasty and balloon kyphoplasty. Conclusion: Both vertebroplasty and balloon kyphoplasty have a statistically significant advantage in terms of final clinical indicators compared to conservative treatment at low and clinically justified risks. No statistically significant differences were found between the surgical techniques on most of the studied criteria, which would justify the significantly higher cost of kyphoplasty.
\end{abstract}

Key words: vertebroplasty, balloon kyphoplasty, osteoporotic vertebral fractures

\section{INTRODUCTION}

The osteoporosis is a global problem with significant health, social and financial consequences. According to the International Osteoporosis Foundation (IOF) from 2010, it affects more than 22 million women and 5.5 million men between the ages of 50 and 85 in the European Union. Due to the increase in the average age, this number is expected to reach about 34 million patients by 2025. In 2010, more than 3 million new bone fractures due to reduced bone mineral density were presented $-620,000$ fractures of the femur, 520,000 vertebral fractures and $1,800,000$ others. It is estimated that they have led directly or indirectly to at least 43,000 deaths, with the total number of lost so-called Quality-Adjusted Life Years (QUALYs) is estimated at $1,180,000$ [1]. In well-developed countries such as Switzerland, hospital stays for new osteoporotic fractures exceed those associated with acute myocardial infarction, stroke and breast cancer each year, and represent a relatively superior financial problem [2].

The osteoporosis precipitates the occurrence of compression vertebral fractures, even in daily activities and low-energy traumatic accidents. In world statistics, about 3 new osteoporotic vertebral compression fractures (OVCF) occur every minute in men and women over the age of 50 years [3]. The total cumulative risk of developing a new fracture in women over this age is $16 \%$, in men about $5 \%$ [3]. Women over 65 with available OVCF have a $25 \%$ risk of developing a new one in the next 5 years [4], as well as a significantly increased risk of fractures of other bones [5-10]. On the other hand, more than half of patients hospitalized for femoral fracture have evidence of previous OVCF [11].

In practice, the timely diagnosis of OVCF is often missed, as the pain is interpreted as a consequence of another disease of the musculoskeletal and nervous system - radiculitis, plexus irritation, disc disease and others. As a consequence, about $70 \%$ of OVCFs remain clinically unexamined and, correspondingly, incorrectly or incompletely treated [12].

\section{Clinical characteristics}

The most common clinical presentation of OVCF is axial pain syndrome - pain along the spine, spasm of paravertebral musclec and forced analgesic posture. Typical for this type of pain is its intensification when changing the position of the body - from lying or sitting to standing, as well as the relative improvement of symptoms at rest and stationary or supported body position. The clinical picture may be accompanied by excitatory and deficient neurological manifestations depending on whether fragments of the fractured vertebral body compress on nerve structures. With the 
accumulation of multiple osteoporotic fractures with progressive reduction of the height of the spine and the subsequent kyphotic deformity, significantly more serious and difficult to treat problems appear, such as sagittal imbalance, reduction of vital lung capacity and additional cardiovascular system load.

Despite its occult clinical course in a high-risk patient with existing axial pain symptoms and no other etiopathogenetic mechanism, OVCS should be suspected.

\section{IMAGING DIAGNOSTICS}

Many different methods for assessing vertebral fractures and measuring bone mineral density (BMD) are known in practice, but to date the three main imaging studies in these patients remain: radiography, computed tomography and magnetic resonance imaging.

\section{Radiographs}

Lateral radiographs, which are the imaging tool used most recently in practice (Fig. 1 and 2), have diagnostic value with over $20 \%$ reduction in the height of the vertebral body [13]. It decreases significantly when there is more than one osteoporotic fracture in the studied segment, which makes the assessment of acute versus chronic fracture very difficult and in many cases impossible [4]. In practice other methods are available to assess existing osteoporotic fractures based on radiographic images - dual-energy X-ray absorptiometry (DXA) and morphometric x-ray absorptiometry (MXA), but their additional study shows their lower diagnostic accuracy and specificity than that of simple lateral radiography [14].

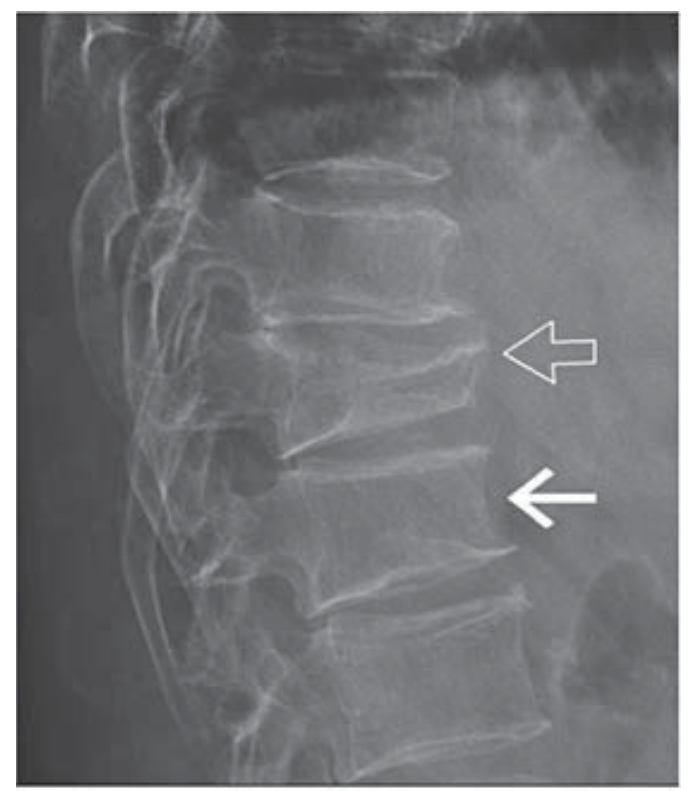

Fig. 1. Patient with high-grade (hollow arrow) and lowgrade (solid arrow) OVCF

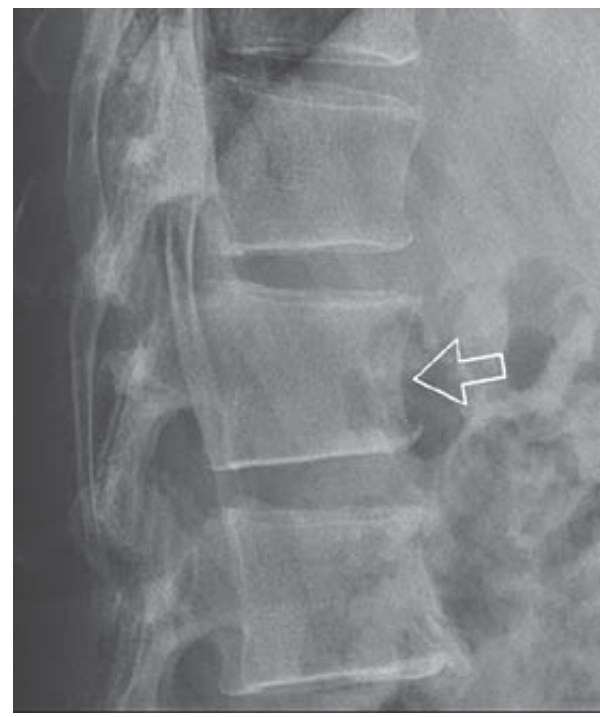

Fig. 2. Physiological wedge-shaped deformation - the so-called ,wedging" of the vertebral body

Fast to perform, easily accessible and with minimal radiation load, this tool should be the first line of the diagnostic process. It should be noted that lateral radiographs make it difficult to fully image the vertebrae of the upper segment of the thoracic spine, due to the overlap of other structures of the shoulder girdle and the greater density of the costal arches. However, this rarely interferes with the diagnostic process, as the bulk of OVCFs occur below the Th6 level.

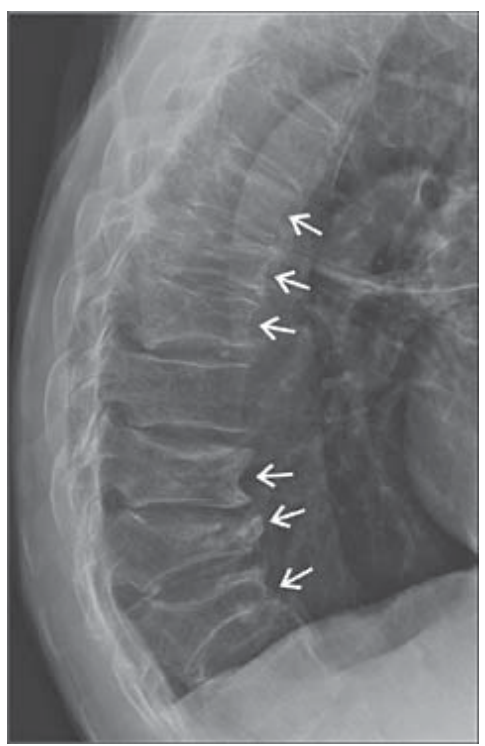

Fig. 3. Patient with a cascade of fractured vertebrae

In the presence of low-grade fractures or multiple adjacent OVCFs (cascades of fractured vertebrae), it becomes significantly more difficult to assess the source of the patient's pain symptoms on the basis of a single radiograph. With such an X-ray image, it is practically impossible to determine with 
certainty which of the fractured vertebrae is the main generator of pain in the patient (Fig. 3). It is possible that most of the fractures depicted are in a chronic stage of consolidation and do not require additional therapeutic attention and follow-up.

\section{Computed tomography}

Computed tomography (CT) provides significantly more information on the morphology of the fracture compared to the two-dimensional image presented by radiographs, but even this much more modern study suffers from the same shortcomings in differentiating between chronic asymptomatic fractures and those generating pain symptoms, especially when observed multiple neighboring OVCFs [15]. On the other hand, this modality is of direct importance in preoperative planning in complex cases.

\section{Magnetic resonance imaging (MRI)}

Despite its significantly higher cost and the time required to perform magnetic resonance imaging (MRI), it remains the most informative of the three main modalities for examining patients with suspected OVCF. On the basis of a well-conducted examination of the relevant segment of the spine, the presence of a low-grade but symptomatic vertebral fracture can be determined with great accuracy, as well as the etiology of the fracture - osteoporotic or pathological. In this way, fractures can be sifted out in chronic stages, which are not the cause of new axial pain. An illustrative case is shown in Fig. 4.

Using the various protocols used in magnetic resonance imaging, we can very accurately distinguish the chronic from acute fractures based on changes in signal intensity, as well as to assess the available pathological changes in the joint-ligament and disc apparatus between the individual vertebrae, which can impose a significant change in the therapeutic plan and in particular in the surgical approach.

\section{SURGICAL TREATMENT}

Treatment of osteoporosis as the underlying disease reduces the risk of new vertebral fractures in $30-70 \%$ of those studied $[16,17]$. In the presence of clinically manifested OVCF, it can be both conservative, which is beyond the interest of the current review, and through minimally invasive surgical techniques - vertebroplasty and kyphoplasty, which we focus on here.

\section{Vertebroplasty}

Vertebroplasty (VPL) was introduced in practice in 1980, initially for the treatment of pathological fractures and local control of cancer. For the last 40 years, the tools for performing the surgical intervention and the physicochemical characteristics of the bone cements have undergone significant development, which improves the safety profile of this procedure.

The surgical procedure is performed under fluoroscopic control, locating the pedicle of the affected vertebra. A cannula is inserted into the latter, which is inserted at a depth of about $2 / 3$ of the vertebral body, after which "bone cement" is introduced under high pressure, the main ingredient of which is
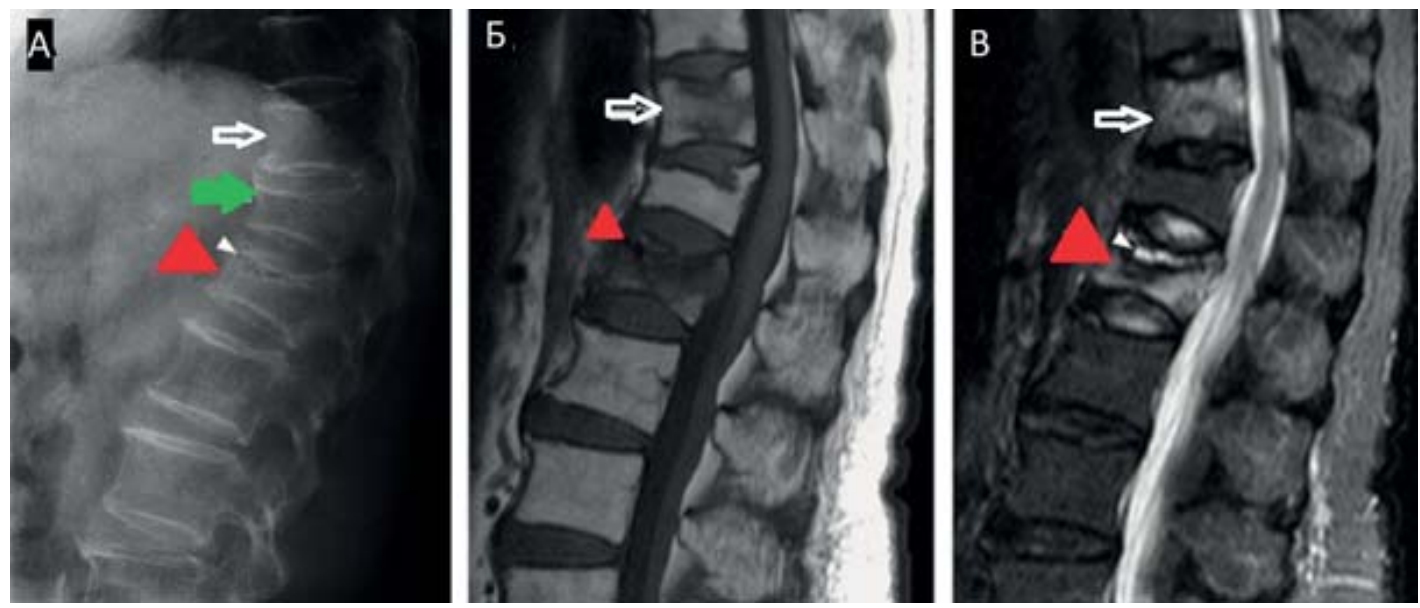

Fig. 4. X-rays and MRI of the thoracolumbar transition. Lateral radiography (A) showed two fractures - Th12 and L1, with evidence of significant stratification and suspicion of a liquid collection below the upper end-plate of L1. When performing MRI (B and C) it is understood that there is a fracture in the body of Th11, which is not visible on lateral radiography. On the sequences that use the protocol for suppression of the signal of the fatty tissue STIR (B) we can differentiate the tissues with the presence of edema in them according to the increased signal intensity. It is clear that the bodies of Th11 and L1 are freshly fractured and are most likely the main generator of axial pain. The Th12 fracture is chronic, consolidated, and probably not a source of pain 
polymethyl methacrylate. There are products with different viscosity and rate of hardening depending on the needs and largely on the preferences of the surgeon.

\section{Kyphoplasty}

Kyphoplasty (KPL) is similar to the previous procedure with one main difference - the use of a balloon, which on the principle of a hydraulic cushion is inflated in the vertebral body in order to lift the lowered end plates and restore the sagittal size of the vertebral body.

Surgical technique involves cannulating the pedicles of the vertebrae in the same way. A balloon is inserted into the vertebral body through the needle, which is inflated to the desired volume with the help of a hydraulic device in order to correct the craniocaudal size of the vertebral body. When inflated, the latter creates a cavity in the collapsed trabecular structure of the body. After removing the balloon through the same cannulas, bone cement is introduced, in this case under low pressure, which fills the created cavities and fixes the vertebral body. The individual steps are presented in Fig. 5. There are also alternative devices that resemble a metal jack from a special alloy and are integrated into the vertebral body.

\section{LITERATURE REVIEW}

The aim of the current study was to compare the three main methods of treatment of osteoporot- ic compression vertebral fractures - conservative treatment, vertebroplasty and kyphoplasty, by key clinical endpoints, which include pain control, quality of life, functionality and safety profile.

\section{MATERIAL AND METHODS}

We searched the global literature for randomized clinical trials and meta-analyzes comparing the three main methods of treating OVCF to show statistically significant large-scale differences. We compared with them our clinical experience for the last 10 years.

\section{RESULTS}

From the analysis of the collected information, a significant discrepancy was found in the large randomized trials regarding the therapeutic superiority of surgical procedures compared to conservative treatment. Some authors claim that the therapeutic superiority of vertebro- and kyphoplasty in terms of pain and quality of life is exhausted within 6-12 months of the follow-up period, with patients in the interventional and conservative arm in the series of Rousing et al. show a leveling offset towards the end of the follow-up [18].

Significant superiority in the immediate postoperative period is reported in almost all publications [19-25]. Exceptions are two studies by Buchbiner et al. and Kallmes et al., who compared vertebroplasty with a placebo procedure in which no statistically
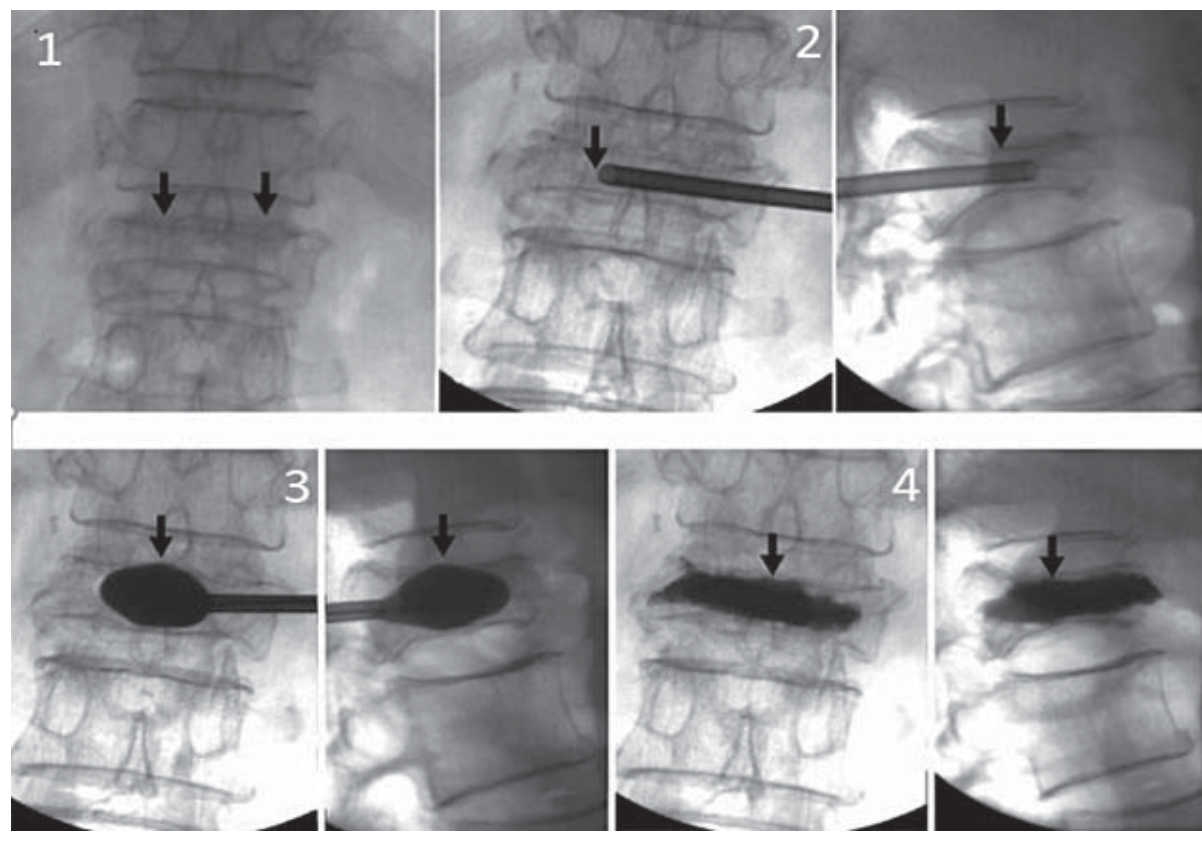

Fig. 5. Intraoperative radiographs of performed kyphoplasty: 1. On the facial projection are the pedicles of the vertebrae. 2. Transpedicularly under fluoroscopic control in the facial and lateral projection is introduced a cannula to 2/3 of the depth of the body. 3. A balloon is inserted into the cannula, which is inflated until a satisfactory correction of the sagittal size of the body is reached. 4. After removing the balloon, the X-ray positive bone cement is introduced into the newly created cavity 
significant difference was observed between the operative group and the placebo-treated group in the early postoperative period [26, 27]. The randomized clinical trials are presented in Table 1.

Table. 1. Randomized clinical trials comparing surgical treatment to the best conservative

\begin{tabular}{|c|c|c|c|c|c|}
\hline Author & $\mathrm{N}$ & Therapy & Age, years & $\begin{array}{l}\text { Follow-up, } \\
\text { months }\end{array}$ & $\begin{array}{c}\text { Superiority of VPL/KPL } \\
\text { over control group }\end{array}$ \\
\hline \multirow{2}{*}{$\begin{array}{l}\text { Chen } \\
2014(19)\end{array}$} & 46 & VPL & 65 & \multirow{2}{*}{12} & \multirow{2}{*}{ Yes } \\
\hline & 43 & Conservative & 66 & & \\
\hline \multirow{2}{*}{$\begin{array}{l}\text { Xie } \\
2013(20)\end{array}$} & 77 & KPL & 67 & \multirow{2}{*}{9} & \multirow{2}{*}{ No } \\
\hline & 87 & Conservative & 67 & & \\
\hline \multirow{2}{*}{$\begin{array}{l}\text { Blasco } \\
2012(21)\end{array}$} & 64 & VPL & 71 & \multirow{2}{*}{12} & \multirow{2}{*}{ Yes, up to 2 months } \\
\hline & 61 & Conservative & 75 & & \\
\hline \multirow{2}{*}{$\begin{array}{l}\text { Farrokhi } \\
2011(22)\end{array}$} & 40 & VPL & 72 & \multirow{2}{*}{36} & \multirow{2}{*}{ Yes, incl. after 36 months } \\
\hline & 42 & Conservative & 74 & & \\
\hline \multirow{2}{*}{$\begin{array}{l}\text { Boonen } \\
2011(23)\end{array}$} & 149 & KPL & 72 & \multirow{2}{*}{9} & \multirow{2}{*}{$\begin{array}{l}\text { Yes, regarding pain, no } \\
\text { difference in } \mathrm{HRQOL}\end{array}$} \\
\hline & 151 & Conservative & 74 & & \\
\hline \multirow{2}{*}{$\begin{array}{l}\text { Klazen } \\
2010(24)\end{array}$} & 101 & VPL & 75 & \multirow{2}{*}{11} & \multirow{2}{*}{ Yes } \\
\hline & 101 & Conservative & 75 & & \\
\hline \multirow{2}{*}{$\begin{array}{l}\text { Rousing } \\
2010 \text { (18) }\end{array}$} & 25 & VPL & 80 & \multirow{2}{*}{12} & \multirow{2}{*}{ Yes, up to 6-12 months } \\
\hline & 24 & Conservative & 80 & & \\
\hline \multirow{2}{*}{$\begin{array}{l}\text { Kallmes } \\
2009(27)\end{array}$} & 68 & VPL & 73 & \multirow{2}{*}{1} & \multirow{2}{*}{ No } \\
\hline & 63 & Placebo & 74 & & \\
\hline \multirow{2}{*}{$\begin{array}{l}\text { Buchbinder } \\
2009 \text { (26) }\end{array}$} & 38 & VPL & 74 & \multirow{2}{*}{6} & \multirow{2}{*}{ No } \\
\hline & 40 & Placebo & 79 & & \\
\hline \multirow{2}{*}{$\begin{array}{l}\text { Voormolen } \\
2007 \text { (25) }\end{array}$} & 18 & VPL & 72 & \multirow{2}{*}{0.5} & \multirow{2}{*}{ Yes } \\
\hline & 16 & Conservative & 74 & & \\
\hline
\end{tabular}

Despite its minimally invasive nature, both any surgical intervention and VPL and KPL have adverse events related to the procedure. The most common complications considered in practice are:

- Leakage of bone cement to the paravertebral space and spinal canal;

- Neurological complications from direct surgical trauma;

- Pulmonary thromboembolism - both associated with bone cement embolism due to intravenous intravasation, and from mobilized organized thrombi in long-term patients who are at high risk;

- Infections related to the procedure - the surgical wound, spondylitis, etc.;

- Acute myocardial infarction;

- Epidural hematomas;

- Fractures of adjacent vertebrae, etc.

It is worth noting that some of these complications can be observed with a significant delay, somehow speculatively. Prokop et al reported a case of myocardial perforation from a cement embolus two and a half years after kyphoplasty without any previous symptoms from the cardiovascular system [28]. The conclusions of the meta-analysis of Jason et al. on the generally reported complications related to KPL and VPL are presented in Table 2 [29].

Of the six randomized clinical trials comparing $\mathrm{VPL}$ and $\mathrm{KPL}$ on the main endpoints - pain, quality of life and functionality on the relevant indicators, there was no statistically significant difference in the effect of treatment, both in the direct postoperative outcome and in follow-up to 5 years in some of the publications, Table 3 [30-34].

The authors, comparing the two main operative procedures, noted as the only superiority of KPL over VPL the lower risk of cement leakage to the paravertebral anatomical structures. They note that the phenomenon is at the expense of intraoperative observations, which remain clinically mute and without the additional risk of postoperative complications associated with the procedure [33]. Their overall conclusion is that the additional financial burden that the KPL represents compared to the VPL is not justified with clinically equal end results in terms of quality of life, pain and functional recovery.

Table 2. Comparison of complications due to vertebroplasty and kyphoplasty from the data of Jason C. et al. [29]

\begin{tabular}{|l|l|l|l|}
\hline $\begin{array}{l}\text { Observed } \\
\text { complication }\end{array}$ & VPL (\%) & KPL (\%) & $\begin{array}{l}\text { Statistical } \\
\text { significance }\end{array}$ \\
\hline Cement leakage & $\begin{array}{l}1838 / 9330 \\
(19.7)\end{array}$ & $213 / 3034(7.0 \%)$ & $<0.001$ \\
\hline $\begin{array}{l}\text { Symptomatic cement } \\
\text { leakage }\end{array}$ & $\begin{array}{l}65 / 4125 \\
(1.6 \%)\end{array}$ & $3 / 963(0.3 \%)$ & $<0.01$ \\
\hline $\begin{array}{l}\text { New adjacent level } \\
\text { fracture }\end{array}$ & $\begin{array}{l}565 / 3159 \\
(17.9)\end{array}$ & $134 / 947(14.1)$ & $<0.1$ \\
\hline $\begin{array}{l}\text { Acute myocardial } \\
\text { infarction }\end{array}$ & $\begin{array}{l}1 / 1938 \\
(0.05)\end{array}$ & $5 / 951(0.5)$ & $<0.1$ \\
\hline $\begin{array}{l}\text { Pulmonary } \\
\text { thromboembolism }\end{array}$ & $\begin{array}{l}33 / 3601 \\
(0.9)\end{array}$ & $2 / 565(0.4)$ & No \\
\hline Hematoma & $6 / 2396(0.3)$ & $1 / 603(0.1)$ & No \\
\hline Infection & $3 / 2192(0.1)$ & $2 / 646(0.3)$ & No \\
\hline
\end{tabular}


Table 3. Conclusions from randomized clinical trials comparing VPL and KPL

\begin{tabular}{|c|c|c|c|c|c|}
\hline Author & $N$ & Therapy & $\begin{array}{l}\text { Age, } \\
\text { years }\end{array}$ & $\begin{array}{c}\text { Follow-up, } \\
\text { months }\end{array}$ & $\begin{array}{l}\text { Therapeutic } \\
\text { advantage }\end{array}$ \\
\hline \multirow{2}{*}{$\begin{array}{l}\text { Zhou } \\
2015 \text { (30) }\end{array}$} & 40 & VPL & 66 & \multirow{2}{*}{12} & \multirow{2}{*}{ No } \\
\hline & 40 & KPL & 66 & & \\
\hline \multirow{2}{*}{$\begin{array}{l}\mathrm{Li} \\
2015(31)\end{array}$} & 30 & VPL & 70 & \multirow{2}{*}{0,1} & \multirow{2}{*}{$\begin{array}{c}\text { No, less leakage } \\
\text { in KPL }\end{array}$} \\
\hline & 30 & KPL & 70 & & \\
\hline \multirow{2}{*}{$\begin{array}{l}\text { Endres } \\
2012 \text { (32) }\end{array}$} & 20 & VPL & 63 & \multirow{2}{*}{6} & \multirow{2}{*}{$\begin{array}{c}\text { No, VPL is } \\
\text { cheaper procedure }\end{array}$} \\
\hline & 21 & KPL & 71 & & \\
\hline \multirow{2}{*}{$\begin{array}{l}\text { Evans } \\
2016 \text { (33) }\end{array}$} & 59 & VPL & 75 & \multirow{2}{*}{12} & \multirow{2}{*}{ No } \\
\hline & 56 & KPL & 76 & & \\
\hline \multirow{2}{*}{$\begin{array}{l}\text { Dohm } \\
2014 \text { (34) }\end{array}$} & 191 & VPL & 76 & \multirow[b]{2}{*}{24} & \multirow{2}{*}{$\begin{array}{l}\text { KPL is less } \\
\text { leakage of new } \\
\text { fractures }\end{array}$} \\
\hline & 190 & KPL & 76 & & \\
\hline \multirow{2}{*}{$\begin{array}{l}\text { Liu } \\
2010(35)\end{array}$} & 50 & VPL & 72 & \multirow{2}{*}{60} & \multirow{2}{*}{ No } \\
\hline & 50 & KPL & 74 & & \\
\hline
\end{tabular}

\section{Discussion}

Both vertebroplasty and kyphoplasty are relatively easy to perform, minimally invasive surgical procedures. From our experience, the intervention does not take more than 60 minutes, even if it is necessary to intervene more than one - up to 4 vertebrae per procedure. It can also be performed under local infiltration, spinal or epidural anesthesia, which we perform in disabled patients who do not tolerate intubation. Patients can be mobilized once the direct effects of the drugs administered have passed.

In our practice for the last 10 years more than 850 procedures for VPL and KPL have been performed at OVCF, and our personal experience in comparing the two procedures is comparable to that of the world literature. Despite a significant correction in the kyphotic deformity during kyphoplasty and restoration of the level of the vertebral body by 25 $50 \%$, the patients did not show a statistically significant difference in the indicators of quality of life and restoration of functionality. On the other hand, the operative approaches discussed outperform conservative treatment in assessing quality of life related to health and functionality, even with a follow-up period of more than 5 years.

Randomized clinical trials and published meta-analyzes show a statistically significant superiority of minimally invasive procedures over conservative treatment in terms of pain assessment. This difference is most pronounced in the direct postoperative period. The statement that with a long follow-up period (over 24 months) the procedures lead to results comparable to that of conservative behavior remains relatively debatable. The general opinion is that two years is too long a follow-up period for a pathology that leads to significant pain and changes in quality of life and where direct and short-term results have much greater clinical value. An additional disadvantage in the long-term follow-up of patients with major pain-related symptoms is the absolute subjective nature of pain assessment. Daily functions and quality of life related to health can be objectively assessed by known and widespread systems (SF-36, QUALEEFO, $H R Q o L Q, O D I$, etc.), but in practice the fully subjective visual analog scale is still used to assess pain (VAS). The disadvantage of these estimates is that they are based on the individual's current comparison framework. A large proportion of patients over the age of 60 cannot be completely sure exactly how much more severe the pain was 2 years ago than it was at the end of a long follow-up period.

\section{Conclusion}

In practice, too often the timely diagnosis of osteoporosis and even its complications, in particular osteoporotic compression vertebral fractures, is missed. A more aggressive skinning process is needed for everyone in the risk contingent, due to the significant medical, social and financial consequences of this disease.

In the presence of axial pain in a patient with risk factors, generally over 50 years of age and female, it is necessary to perform imaging studies - radiography, CT, MRI of the relevant segment of the spine. Despite its significantly higher cost, MRI is the most informative of the listed studies and we recommend it in all cases when there is no definitive data on pathology by radiography or in a large number of affected vertebrae, as well as whenever I have available neurological symptoms except axial pain.

Vertebroplasty as well as kyphoplasty have better results in controlling pain with the fastest possible effect. With the exception of the slightly more common, but almost always asymptomatic, leaks of cement in VPL, the two procedures are absolutely comparable in terms of final clinical results - quality of life related to health and functionality. In the same sense, both have a high safety profile, with reported complications that potentially endanger patients" lives occurring in less than $1 \%$ of cases. However, the significantly higher cost of kyphoplasty makes it less applicable. If it is impossible to achieve adequate pain control in a short period - up to 2 weeks with the help of conservative methods, we recommend percutaneous vertebroplasty. 


\section{Author's Declaration}

The authors declare that the material has not been published before.

\section{Библиография / References}

1. Hernlund $E$, Svedbom $A$, Ivergård $M$ et al. Osteoporosis in the European Union: medical management, epidemiology and economic burden: A report prepared in collaboration with the International Osteoporosis Foundation (IOF) and the European Federation of Pharmaceutical Industry Associations (EFPIA). Arch Osteoporos. 2013 Dec;8(1-2):136.

2. Lippuner K, Von Overbeck J, Perrelet R et al. Incidence and Direct Medical Costs of Hospitalizations due to Osteoporotic Fractures in Switzerland. Osteoporos Int. 1997 Sep 1;7(5):414-25.

3. Johnell O, Kanis JA. An estimate of the worldwide prevalence and disability associated with osteoporotic fractures. Osteoporos Int J Establ Result Coop Eur Found Osteoporos Natl Osteoporos Found USA. 2006 Dec;17(12):1726-33.

4. Kaptoge S, Armbrecht G, Felsenberg D et al. When Should the Doctor Order a Spine X-Ray? Identifying Vertebral Fractures for Osteoporosis Care: Results From the European Prospective Osteoporosis Study (EPOS). J Bone Miner Res. 2004;19(12):1982-93.

5. Hasserius R, Karlsson MK, Nilsson BE, I., Johnell O. Prevalent vertebral deformities predict increased mortality and increased fracture rate in both men and women: A 10-year population-based study of 598 individuals from the Swedish cohort in the European Vertebral Osteoporosis Study. Osteoporos Int. 2003 Jan 1;14(1):61-8.

6. Klotzbuecher CM, Ross PD, Landsman PB et al. Patients with prior fractures have an increased risk of future fractures: a summary of the literature and statistical synthesis. $\mathrm{J}$ Bone Miner Res Off J Am Soc Bone Miner Res. 2000 Apr;15(4):721-39.

7. Lindsay R, Silverman SL, Cooper $\mathrm{C}$ et al. Risk of new vertebral fracture in the year following a fracture. JAMA. 2001 Jan 17;285(3):320-3.

8. Ross PD. Pre-Existing Fractures and Bone Mass Predict Vertebral Fracture Incidence in Women. Ann Intern Med. 1991 Jun 1;114(11):919.

9. Cauley JA, Palermo L, Vogt M et al. Prevalent Vertebral Fractures in Black Women and White Women. J Bone Miner Res. 2008 Sep;23(9):1458-67.

10. Roux C, Fechtenbaum J, Kolta $S$ et al. Mild prevalent and incident vertebral fractures are risk factors for new fractures. Osteoporos Int. 2007 Dec 1;18(12):1617-24.

11. Gonnelli S, Caffarelli C, Maggi S et al. The assessment of vertebral fractures in elderly women with recent hip fractures: the BREAK Study. Osteoporos Int. 2013 Apr 1;24(4):1151-9.

12. Cooper C, Atkinson EJ, O'Fallon WM, Melton LJ. Incidence of clinically diagnosed vertebral fractures: a population-based study in Rochester, Minnesota, 1985-1989. J Bone Miner Res Off J Am Soc Bone Miner Res. 1992 Feb;7(2):221-7.

13. Griffith JF. Identifying osteoporotic vertebral fracture. Quant Imaging Med Surg. 2015 Aug 24;5(4):592-602-602.

14. Felsenberg D, Gowin W, Diessel E et al. Recent developments in DXA. Quality of new DXA/MXA-devices for densitometry and morphometry. Eur J Radiol. 1995 Sep 1;20(3):179-84.

15. Williams A, Al-Busaidi A, Sparrow $P$ et al. Under-reporting of osteoporotic vertebral fractures on computed tomography. Eur J Radiol. 2007 Oct 1;69:179-83.

16. Kanis JA, Burlet N, Cooper $C$ et al. European guidance for the diagnosis and management of osteoporosis in postmenopausal women. Osteoporos Int J Establ Result Coop Eur Found Osteoporos Natl Osteoporos Found USA. 2008 Apr;19(4):399-428.

17. Black DM, Delmas PD, Eastell R et al. Once-yearly zoledronic acid for treatment of postmenopausal osteoporosis. $\mathrm{N} \mathrm{Engl}$ J Med. 2007 May 3;356(18):1809-22.

18. Rousing R, Hansen $\mathrm{KL}$, Andersen $\mathrm{MO}$ et al. Twelve-months follow-up in forty-nine patients with acute/semiacute osteoporotic vertebral fractures treated conservatively or with percutaneous vertebroplasty: a clinical randomized study. Spine. 2010 Mar 1;35(5):478-82.

19. Chen $D, A n Z-Q$, Song $S$ et al. Percutaneous vertebroplasty compared with conservative treatment in patients with chronic painful osteoporotic spinal fractures. J Clin Neurosci Off J Neurosurg Soc Australas. 2014 Mar;21(3):473-7.

20. En X, Hao D-J. Percutaneous Kyphoplasty versus Conservative Treatment in Acute and Subacute Osteoporotic Vertebral Compression Fractures (OVCF): A Double-Blinded, Randomized Controlled Clinical Trial (RCT) in the Population of Western China. Spine J. 2013 Sep 1;13(9):S90-1.

21. Blasco J, Martinez-Ferrer A, Macho J et al. Effect of vertebroplasty on pain relief, quality of life, and the incidence of new vertebral fractures: a 12-month randomized follow-up, controlled trial. J Bone Miner Res Off J Am Soc Bone Miner Res. 2012 May;27(5):1159-66.

22. Farrokhi MR, Alibai E, Maghami Z. Randomized controlled trial of percutaneous vertebroplasty versus optimal medical management for the relief of pain and disability in acute osteoporotic vertebral compression fractures. J Neurosurg Spine. 2011 May;14(5):561-9.

23. Boonen S, Van Meirhaeghe J, Bastian L et al. Balloon kyphoplasty for the treatment of acute vertebral compression fractures: 2-year results from a randomized trial. J Bone Miner Res Off J Am Soc Bone Miner Res. 2011 Jul;26(7):1627-37.

24. Klazen CAH, Lohle PNM, de Vries J et al. Vertebroplasty versus conservative treatment in acute osteoporotic vertebral compression fractures (Vertos II): an open-label randomised trial. Lancet Lond Engl. 2010 Sep 25;376(9746):1085-92.

25. Voormolen MHJ, Mali WPTM, Lohle PNM et al. Percutaneous vertebroplasty compared with optimal pain medication treatment: short-term clinical outcome of patients with subacute or chronic painful osteoporotic vertebral compression fractures. The VERTOS study. AJNR Am J Neuroradiol. 2007 Mar;28(3):555-60.

26. Buchbinder R, Osborne RH, Ebeling PR et al. A randomized trial of vertebroplasty for painful osteoporotic vertebral fractures. N Engl J Med. 2009 Aug 6;361(6):557-68.

27. Kallmes DF, Comstock BA, Heagerty PJ et al. A randomized trial of vertebroplasty for osteoporotic spinal fractures. $\mathrm{N}$ Engl J Med. 2009 Aug 6;361(6):569-79.

28. Prokop A, Hägele M, Pfeilsticker U et al. [Pericardial perforation 2.5 years after kyphoplasty. A rare complication after cement extravasation]. Unfallchirurg. 2013 Jan;116(1):80-4.

29. Eck J, Nachtigall D, Humphreys S, Hodges S. Comparison of vertebroplasty and balloon kyphoplasty for treatment of vertebral compression fractures: a meta-analysis of the lit- 
erature. Orthop Phys Rehabil Publ [Internet]. 2008 May 26;8(3). Available from: https://escholarship.umassmed.edu/ ortho_pp/49

30. Zhou W. Percutaneous vertebroplasty with high-viscosity bone cement for treatment of severe osteoporotic thoracolumbar vertebral compression fractures. Chin J Tissue Eng Res. 2015 Jan 1;(46):7534-8.

31. Li D, Liu $X$, Peng $X$ et al. Bone filling mesh container for treatment of vertebral compression fractures can reduce the leakage of bone cement. Chin J Tissue Eng Res. 2015 Jan 1;(3):358-63.

32. Endres S, Badura A. Shield kyphoplasty through a unipedicular approach compared to vertebroplasty and balloon kyphoplasty in osteoporotic thoracolumbar fracture: a prospective

Постъпила за печат: 29.09.2020 г.

$\triangle$ Адрес за кореспонденция:

Д-р Дилян Фердинандов, дм

Клиника по неврохирургия, УМБАЛ „Св. Иван Рилски“

бул. „Акад. Иван Гешов“ 15, София

тел. +359888678549

e-mail: ferdinandov@gmail.com

ORCID ID: https://orcid.org/0000-0002-0923-612X randomized study. Orthop Traumatol Surg Res OTSR. 2012 May;98(3):334-40.

33. Evans AJ, Kip KE, Brinjikji W et al. Randomized controlled trial of vertebroplasty versus kyphoplasty in the treatment of vertebral compression fractures. J Neurointerventional Surg. $2016 \mathrm{Jul} ; 8(7): 756-63$.

34. Dohm M, Black CM, Dacre A et al, KAVIAR investigators. A randomized trial comparing balloon kyphoplasty and vertebroplasty for vertebral compression fractures due to osteoporosis. AJNR Am J Neuroradiol. 2014 Dec;35(12):2227-36.

35. Liu JT, Liao WJ, Tan WC et al. Balloon kyphoplasty versus vertebroplasty for treatment of osteoporotic vertebral compression fracture: a prospective, comparative, and randomized clinical study. Osteoporos Int. 2010 Feb;21(2):359-64.

\section{Submitted: 29.09 .2020}

$\triangle$ Correspondence address:

Dilyan Ferdinandov, MD, MPH, PhD

Clinic of Neurosurgery, Sv. Ivan Rilski University Hospital

15 Acad. Ivan Geshov Blvd, Sofia, Bulgaria

tel. +359888678549

e-mail: ferdinandov@gmail.com

ORCID ID: https://orcid.org/0000-0002-0923-612X 